\title{
THE “DUO”, BUILDING SETBACK AND LANDSCAPE QUALITY: LAUTECH (NIGERIA) NEIGHBOURHOOD EXAMINED
}

\author{
ADEDEJI, Joseph Adeniran \\ Department of Architecture, Ladoke Akintola University of Technology, P.M.B. 4000, Ogbomoso, Oyo State, Nigeria. \\ Email: niranadedeji@yahoo.com \\ FADAMIRO, Joseph Akinlabi \\ Department of Architecture, Ladoke Akintola University of Technology, P.M.B. 4000, Ogbomoso, Oyo State, Nigeria. \\ Email: joechrisdamiro@yahoo.com
}

\begin{abstract}
The subjects, building setbacks and landscape quality, can be considered as "duo" in view of their interwoven relationships as major determinants of open space quality in residential neighbourhoods. In view of the numerous benefits and functions of residential open spaces, these were examined in LAUTECH neighbourhood. The purpose was to assess the compliance level of these land use and outdoor quality variables with the Nigerian planning regulations to guide future developments in these sprawling neighbourhoods. A total sample size of 150 buildings was selected from the study population using stratified method. Direct measurement and observation of these variables was carried out. Result of a descriptive statistical analysis of the data obtained shows that there is a general poor conformity of setbacks, width of access roads and nature of fence to planning standards. These negatively affect building massing and the non-standard open spaces left were poorly landscaped. There were correlations between building setbacks and landscape quality. The result informed recommendations on these subjects for neighbourhoods that abut institutional campuses in general.
\end{abstract}

Keywords: LAUTECH, setback, landscape, open spaces, residential neighbourhood.

\section{INTRODUCTION}

Building setback in urban residential neighborhoods has direct impact on the quantity of the resultant open space around individual building units and landscape quality of the whole neighbourhood. In view of this and in pursuant of healthy living environments, building and planning regulation in Nigeria specifies the minimum standards of building setbacks for residential land use. Nowhere else is the compliance with these planning standards more relevant than in students' residential neighbourhoods. However, casual observation of the study area reveals uncontrolled developments without adequate building setbacks possibly because of high cost of building land in the neighbourhoods (Adedeji et al., 2009). This study therefore seeks to investigate the level of building setback compliance with planning regulation and how the resultant open spaces are landscaped in the study area where a dominant size of LAUTECH students live being an off-campus university system. The study would be of immense importance in guiding future physical developments in these constantly growing neighbourhoods.

Furthermore, open spaces around buildings ensure adequate circulation, ventilation and day lighting (Tipple, 2001). The quantity of open spaces around buildings determines the space that is left for outdoor landscape features and outdoor activities.
Also, there is a working relationship between landscaping and open space management and there is deep need for "adequate knowledge of the concept of open spaces and its super imposition on other concepts such as garden, parks and landscaping in general" (Fadamiro and Atolagbe, 2006). Fadamiro and Atolagbe (2006) denoted landscaping as the process of shaping, modifying and creating an ordered outdoor scene for functional and supportive roles. Such functions include accent, softening, dust screening, framing, shading, enclosure, circulation control, noise control and surfacing. Indeed, the importance of landscaping of open spaces around buildings cannot be overemphasized.

The treatment of residential environments has been discovered to have impact on the health, productivity and recreation of urban dwellers just as landscaping around homes lead to reduction of environmental pollution (Jagboro, 2000). The converse of this discovery is also true. For instance, Oyelami (2005) linked the use of artificial objects around homes with negative effects on health of dwellers. Campbell (2001) posited that open spaces has potential to provide environmental and social benefits to communities whether directly or indirectly.

Landscape elements can be generally grouped into hard and soft classes. Hard landscape elements are usually structural in nature. They include paving, stones, and asphalt. They are generally less desirable. 
On the other hand, soft landscape materials are more desirable and include grass cover, shrubs, palms and trees. According to Braines (2000) there exists a complex relationship between trees and people. In the words of Azwar and Ghain (2009), they provide "the sound of birds, the seasonal display of blossom fruit and changing leaf colour and splendour". They added that domestic gardens in particular offer privacy, security and the opportunity for individuality. Gardens have also been recognized as providing a soft and sheltered setting for the buildings (Jones, 2003) in contrasts to the harshness of buildings and the noise and grime of busy traffic (Jones, 2001). Companies of trees and natural surroundings can also provide measurable stress relief.

Ignorance of these benefits of landscaping among others is the bane of the poor urban environmental aesthetics and function. Lasisi and Arowosegbe (2005) in their study of urban landscaping problems in Ilaro, Nigeria, discovered that misconceptions and ignorance of these benefits hindered majority of respondents from landscaping and maintenance of green open spaces around their dwellings. In residential designs generally, there is usually the provision of the equivalent indoor room as the outdoor rooms. Outdoor room usually have floors of ground cover, concrete paving or timber finish, outdoor walls of plant hedges, sandcrete wall fence or see-through wire fencing depending on the purpose and outdoor ceiling of the natural sky. Adjacent to the living room is the outdoor living provided under a shading tree with ground cover or timber floor patio. Indoor sleeping area is also provided with equivalent adjacent outdoor sleeping area with landscape elements. While the outdoor living and sleeping areas/rooms are used for relaxation, the outdoor kitchen near the indoor kitchen is used for the major service of outdoor cooking which may be heavy occasionally.

Indeed, a balance in the quality of the indoor and outdoor spaces of an architectural structure determines the quality of the entire living environment both at micro (plot) and neighbourhood scales. Akingbohungbe (2003a) remarked that they exact profound impact on the lifestyle, health, happiness, integrity and productivity of residents. Fadamiro (2000) posited that provision of outdoor spaces in development is an essential and integral contributor to the quality of life. In the view of Carmona et al (2003), well-designed landscaping of open spaces adds quality, visual interest and colour. It is for these reasons and the earlier stated ones that The Building Adoptive Bye-Laws Order 1960 for Nigeria specifies in section 8 that:
1. There shall be an open space not less than five feet six inches $(1.65 \mathrm{~m})$ in width between any building and the side boundary of the site where the height of the building does not exceed twenty-five feet $(7.50 \mathrm{~m})$, and an open space not less than ten feet $(3.00 \mathrm{~m})$ in width where the height of the building exceeds twenty-five feet $(7.50 \mathrm{~m})$.

2. Where the height of any main building does not exceed twenty-five feet $(7.50 \mathrm{~m})$ there shall be an open space of ten feet $(3.00 \mathrm{~m})$ in width between the main building and the out-houses appertaining thereto, where the height of the main building exceeds twenty-five feet $(7.50 \mathrm{~m})$ but does not exceed forty feet $(12.00 \mathrm{~m})$ such open space shall not be less than fifteen feet $(4.50 \mathrm{~m})$ in width, and where the height of the main building exceeds forty feet $(12.00 \mathrm{~m})$ such open space shall not be less than twenty feet in width $(6.0 \mathrm{~m})$.

The importance of the treatment of the open spaces around residential 1 buildings brought about the specification of the required height of the fence in Section 21 of the law as follow:

1. The maximum height of fences (including live fences) around any building site shall be fifteen feet $(4.50 \mathrm{~m})$ except in respect of building sites abutting the junction of two or more highways, in which case fences shall be kept sufficiently low to permit clear visibility around the corner for motorists and other road users.

2. In the case of dwelling houses on small plots not exceeding half an acre in area, no boundary walls or fences shall exceed seven feet $(2.10 \mathrm{~m})$ in height.

\section{LAUTECH Neighbourhood: An Overview}

The study area, LAUTECH neighbourhood, is the fast developing land mass that abuts the university campus (Figure 1.0) in the north (Adenike/Adekola area), west (Inuofebi/Yoaco area) and south (Under-G area). Ladoke Akintola University of Technology (LAUTECH) Ogbomoso, Nigeria was established in 1990 as an off-campus residential system for students and staff. The campus is located along the Ogbomoso-Ilorin road.

The off-campus system was a catalyst to the development of the abutting neighbourhoods (Adedeji et al, 2009) majorly for students' hostels. Unfortunately, the haphazard nature of the developments characterized by sprawling coupled with high cost of building land resulted in unnecessary maximization of land use. Because of this, the private developers found it unnecessary to allow statutory setbacks and carry out at least minimum landscaping of the premises (see plates 1-6 above). 


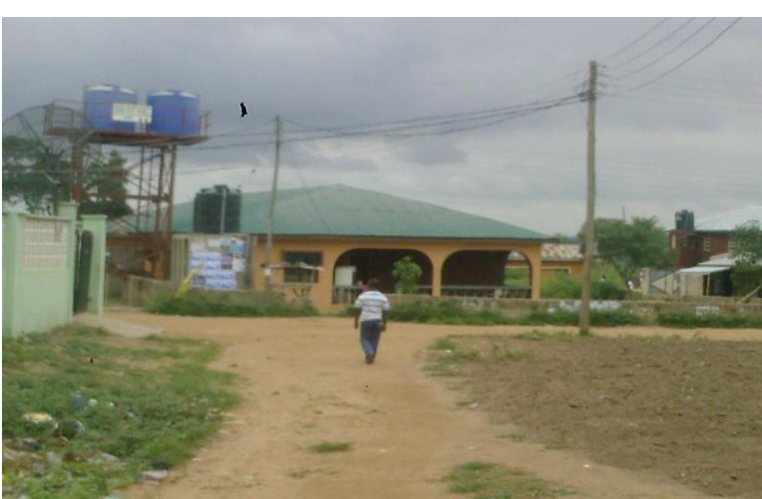

Plate 1. A Students' Hostel with inadequate front setback, without perimeter fence and poorly landscaped open spaces.

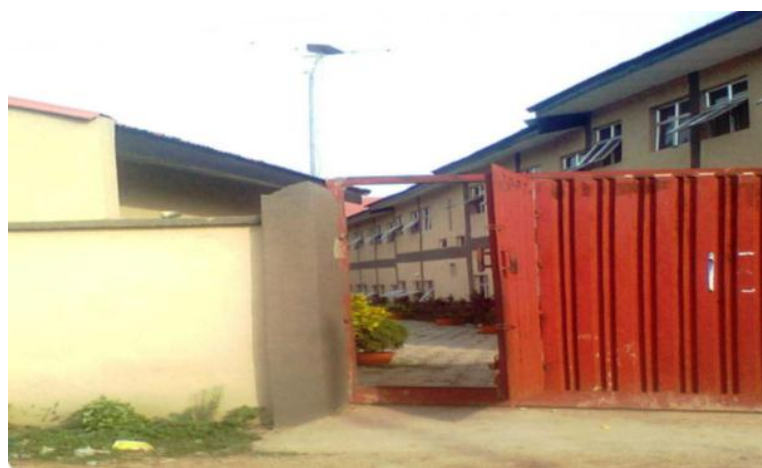

Plate 2. A Students' Hostel with inadequate setbacks, perimeter fence and landscaped with a mix of hard and soft landscape elements.

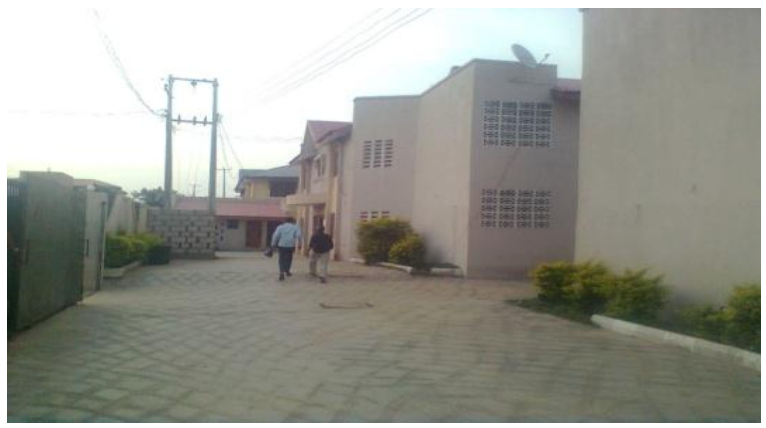

Plate 3. A Students' Hostel with adequate side setback but overwhemingly concrete paved open spaces.

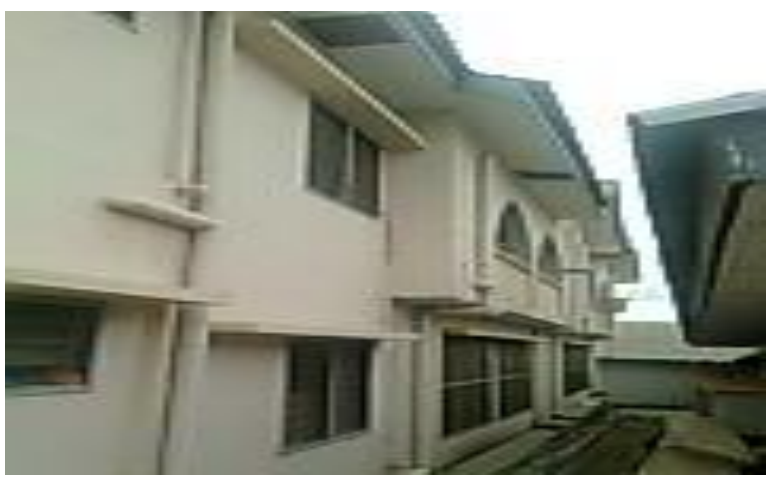

Plate 4. A Students' Hostel with inadequate side setback and open space wide enough for only concrete rain water drainage.

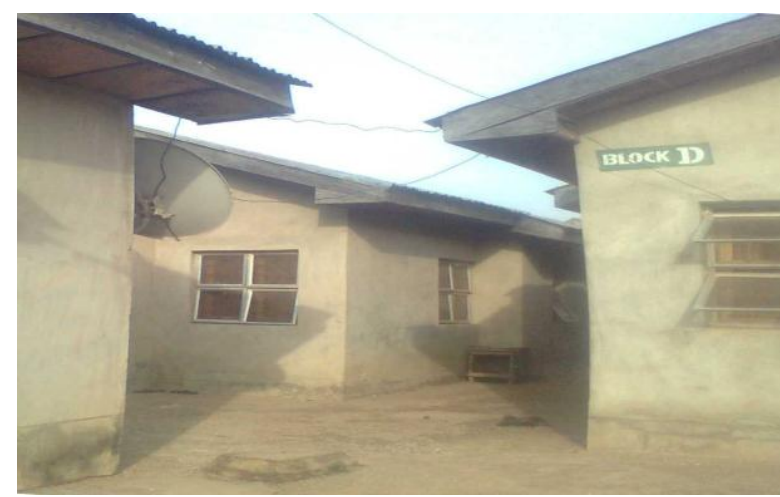

Plate 5. A Students' Hostel with inadequate setback between blocks and concrete paved open spaces without any soft landscape element.

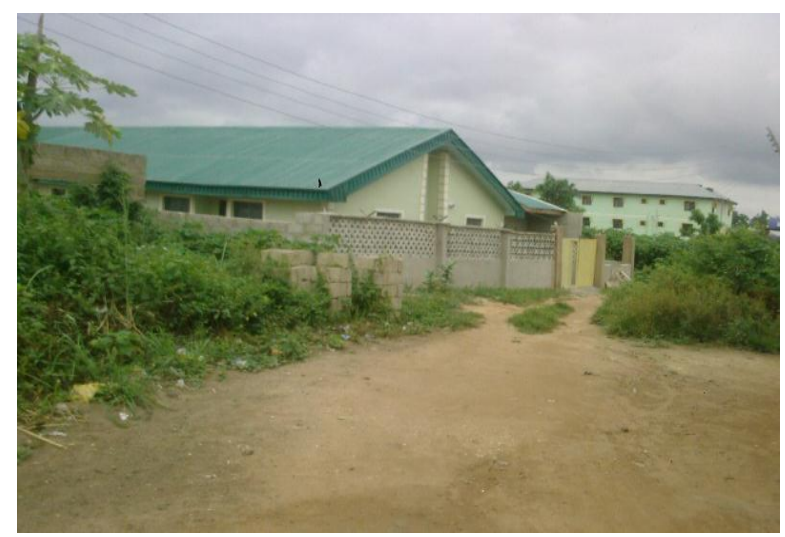

Plate 6. A Students' Hostel with inadequate front and sides setbacks and showing the sprawling nature of the neighbours considering its location.

\section{STUDY METHODOLOGY}

The study population consists of all the buildings in the study area. The whole neighbourhood was divided into three zones (Adenike/Adekola, Inuofebi/ Yoaco, Under G) based on distinct pattern of growth and road network (Figure 1.0). 50 buildings were randomly sampled from each area to give a total of 150 samples. The sampling instrument was a data form that contained information on number of storey, number and width(s) of access road(s), average width of open space on all sides of the building, presence and nature of fence and landscape treatments.

These were directly observed, measured and recorded by trained research assistants. The data obtained was subjected to descriptive and inferential analysis using SPSS statistical package. 


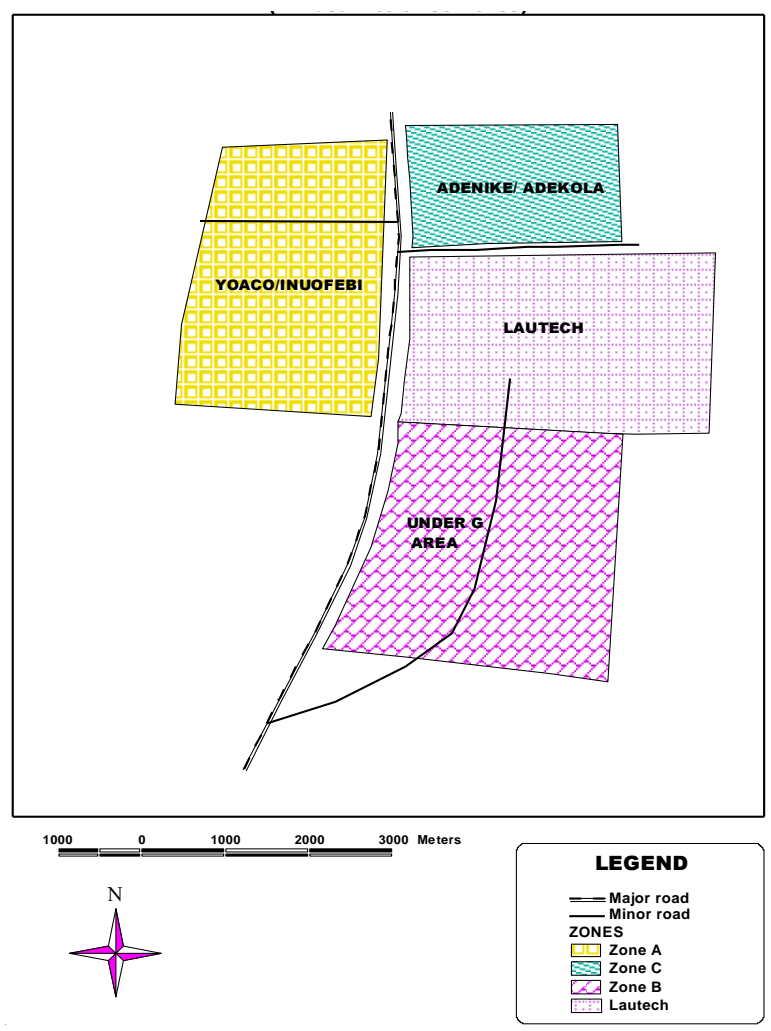

Figure 1. Nap Showing LAUTECH, Ogbomoso and Abutting Meighbourhoods (Divided into three zones)

\section{DISCUSSION OF FINDINGS}

\section{Availability of Open Spaces}

The total sample size of 150 buildings randomly selected for the study (50 per zone) has the following use distribution: $130(86.6 \%)$ residential/students' hostel, 7(4.7\%) guesthouse/hotel, 3(2.0\%) commercial/ business premises, $1(0.7 \%)$ church, $7(4.7 \%)$ mixed development, 2(1.3\%) uncompleted buildings. The number of storey in each building in the sample size are as follow: Bungalow, 14 (9.3\%); one storey, 89(59.3\%); two storeys, 41(27.3\%); not available 6 (4.0\%). Therefore, the set-back to the four sides of the buildings should be the minimum standard. Furthermore, the study reveal that $111(74.0 \%)$ buildings in the sample has 1 access road while 39 (26.0\%) buildings has 2 access roads and Table 1 below shows the widths of the access roads.

The implication is that only a very small number $12(8.0 \%)$ has above $6.0 \mathrm{~m}$ minimum required width for arterial roads as public open space for vehicular and pedestrian circulation while the largest number, $138(92.0 \%)$ fall below standard. Worse still, the $14(9.3 \%)$ buildings with $<3.0 \mathrm{~m}$ width of access road present an extreme case of vehicular inaccessibility and lack of public open space. The users are thus denied the benefits of public circulation space.
Table 1. Width of Access Roads

\begin{tabular}{lrrr}
\hline \multicolumn{3}{l}{ Width of Road Frequency Percent. Cumulative } \\
percent.
\end{tabular}

The open space in front of the buildings in the form of setback of building lines from the property line on the access road sides is presented in Table 2. The largest percentage of the buildings has less than $6.0 \mathrm{~m}$ front setback from access road which not only has negative effect on building massing and driveway turning radius but reduce the size of available open space for landscaping.

Table 2. Set-back from property line in the front to building line

\begin{tabular}{lrrc}
\hline & Frequency Percent. & $\begin{array}{c}\text { Cumulative } \\
\text { percent }\end{array}$ \\
\hline $1.0 \mathrm{~m}-2.0 \mathrm{~m}$ & 17 & 11.3 & 11.3 \\
$2.1 \mathrm{~m}-3.0 \mathrm{~m}$ & 18 & 12.0 & 23.3 \\
$3.1 \mathrm{~m}-4.0 \mathrm{~m}$ & 38 & 25.3 & 48.7 \\
$4.1 \mathrm{~m}-5.0 \mathrm{~m}$ & 37 & 24.7 & 73.3 \\
$5.1 \mathrm{~m}-6.0 \mathrm{~m}$ & 20 & 13.3 & 86.7 \\
$6.1 \mathrm{~m}-7.0 \mathrm{~m}$ & 4 & 2.7 & 89.3 \\
$7.1 \mathrm{~m}-8.0 \mathrm{~m}$ & 8 & 5.3 & 94.7 \\
$8.1 \mathrm{~m}-9.0 \mathrm{~m}$ & 1 & 0.7 & 95.3 \\
$9.1 \mathrm{~m}$ and above & 7 & 4.7 & 100.0 \\
\hline Total & 150 & 100.0 \\
\hline
\end{tabular}

Table 3 shows the average air-space at the leftside of the buildings as available open space. The pattern in Table 3 shows that majority 134 (89.3\%) of the sampled building has the minimum of $1.5 \mathrm{~m}$ side setback.

Table 3. Average air-space at the left side of the building

\begin{tabular}{lrrc}
\hline & Frequency & Percent. & $\begin{array}{c}\text { Cumulative } \\
\text { percent. }\end{array}$ \\
\hline Not available & 2 & 1.3 & 1.3 \\
$<1.5 \mathrm{~m}$ & 14 & 9.3 & 10.7 \\
$1.6-3.0 \mathrm{~m}$ & 56 & 38.6 & 7.3 \\
$3.1-4.5 \mathrm{~m}$ & 49 & 32.7 & 80.7 \\
$4.6-6.0 \mathrm{~m}$ & 4 & 2.7 & 83.3 \\
$>6.0 \mathrm{~m}$ & 25 & 16.7 & 100.0 \\
\hline Total & 150 & 100.0 & \\
\hline
\end{tabular}

The average air-space at the right side of the buildings are as shown in Table 4. Only the 13 (8.7\%) with less than $1.5 \mathrm{~m}$ right side setback are below the minimum standard. However it is usually ideal to provide a minimum of $3.0 \mathrm{~m}$ setback on one of the sides to achieve service drive way to the rear side of the building and for adequate air space. 
Table 4. Average air-space at the right side of the building

\begin{tabular}{lccc}
\hline Air-space & Frequency & Percent. Cumulative percent. \\
\hline Not available & 3 & 2.0 & 2.0 \\
$<1.5 \mathrm{~m}$ & 13 & 8.7 & 10.7 \\
$1.6-3.0 \mathrm{~m}$ & 55 & 36.7 & 47.3 \\
$3.1-4.5 \mathrm{~m}$ & 57 & 38.0 & 85.3 \\
$4.6-6.0 \mathrm{~m}$ & 14 & 9.3 & 94.7 \\
$>6.0 \mathrm{~m}$ & 8 & 5.3 & 100.0 \\
\hline Total & 150 & 100.0 & \\
\hline
\end{tabular}

The setback requirements for the front and sides of the building also depend on the overall height of the building.

The available open space at the rear sides of the buildings are indicated as rear set-back from the property line to the building in Table 5 .

Table 5. Average air-space at the back of the buildings

\begin{tabular}{lrrc}
\hline & Frequency & Percent. & $\begin{array}{c}\text { Cumulative } \\
\text { percent. }\end{array}$ \\
\hline not available & 10 & 6.7 & 6.7 \\
$<1.5 .0 \mathrm{~m}$ & 15 & 10.0 & 16.7 \\
$1.5-3.0 \mathrm{~m}$ & 93 & 62.0 & 78.7 \\
$3.1-4.5 \mathrm{~m}$ & 23 & 15.3 & 94.0 \\
$4.6-6.0 \mathrm{~m}$ & 8 & 5.3 & 99.3 \\
$>6.0 \mathrm{~m}$ & 1 & 0.7 & 100.0 \\
\hline Total & 150 & 100.0 & \\
\hline
\end{tabular}

The minimum standard of rear set back is $1.5 \mathrm{~m}$. Therefore, the 15 (10.0\%) buildings with less than $1.5 \mathrm{~m}$ are below acceptable minimum standard.

\section{Landscape Treatment of the Open Spaces}

The availability of fence wall around the buildings is as follow: $131(87.3 \%)$ of the buildings has fence wall, while $17(11.3 \%)$ buildings have none. The study reveals that the distance between the front fence and the edge of the road are as follow: 21 $(14.0 \%)$ for $0.9 \mathrm{~m}-1.2 \mathrm{~m}, 66(44.0 \%)$ for $1.3 \mathrm{~m}-2.0 \mathrm{~m}$, $21(14.0 \%)$ for $2.1-3.0 \mathrm{~m}$ while $20(13.3 \%)$ buildings have their own as greater than $3.0 \mathrm{~m}$. It is only normal to allow adequate distance between the fence and the edge of the access road to accommodate drainage and services such as water supply mains, underground communication service installations and roadside landscape to achieve urban aesthetics. Even though there is no specified minimum standard for this requirement, a space of $1.3 \mathrm{~m}$ to $2.0 \mathrm{~m}$ between the fence and edge of the access road should be adequate.

Furthermore, the frequency of the overall heights of fence walls on the sides adjacent to the access roads are $1(0.7 \%)$ for $0.9 \mathrm{~m}-1.2 \mathrm{~m}, 46(3.7 \%)$ for $1.3-2.0 \mathrm{~m}$, $81(54.0 \%)$ for $2.1-3.0 \mathrm{~m}$ and $1(0.7 \%)$ for greater than $3 \mathrm{~m}$. Except for corner plots because of traffic safety where a lower height is required, the maximum acceptable height of fence wall on access road side(s) is $2.1 \mathrm{~m}$ and should be see-through. From this pattern, only the $47(31.4 \%)$ buildings with fence walls of height less than $2.1 \mathrm{~m}$ are desirable.

Table 6 shows the general pattern of the hard landscape treatment of the open spaces. Among all the hard landscape materials used, sand walkway has the highest frequency, possibly being the cheapest because there was no need to apply any material. This is indeed a poor landscape solution which lack aesthetic value though does not require any construction cost and better than concrete in terms of thermal comfort. The second range of high frequency is that of cast in-situ concrete paved walkway. Unfortunately, these are not interspersed with soft landscape elements for better thermal comfort of the microclimate.

Similarly, the third range of high frequency is that of cast in-situ concrete paved driveways. Table 6 also shows that there was less use of precast concrete paved walkway. Unfortunately too, these are not interspersed with soft landscape elements a situation that leads to heat storage in the premises and eventual thermal discomfort in the internal room spaces in addition to the reduced landscape aesthetics especially at the ground floor. Parking spaces and lots are not properly demarcated nor finished in majority of the sampled cases. Generally, there was very little care about the hard landscape look of the open space around the $150(100 \%)$ sampled buildings in terms of design, construction and maintenance except for very few isolated exceptional cases. Stone paving's was also scantly used.

Table 7 shows the general pattern of the soft landscape treatment of the open spaces around the buildings in the front and at the other three sides. On the whole, the available open spaces around the sampled buildings were generally badly landscaped with hard elements as well as soft elements and there seem to be no specific landscape designs before the landscape constructions were undertaken. This leads to low landscape quality with obvious non-application of landscape principles like balanced, variety, rhythm and repetition, among others.

\section{Correlation Between Availability of Open Spaces and Landscape Treatment}

To avoid unnecessary rhetoric, only the availability of open spaces in the form of sets back in the front of the buildings were compared with the landscape treatment as shown in the summary of chisquare $\left(\mathrm{x}^{2}\right)$ tables of table 8 . The availability of open spaces around the buildings and in the form of set- 
Table 6. Hard landscape treatment of the open spaces

\begin{tabular}{|c|c|c|c|c|c|c|c|c|}
\hline \multirow{2}{*}{ Landscape treatment } & \multicolumn{2}{|c|}{ Front side } & \multicolumn{2}{|c|}{ Left side } & \multicolumn{2}{|c|}{ Right side } & \multicolumn{2}{|c|}{ Rear side } \\
\hline & Freq./100 & Perc./100 & Freq./150 & Perc./100 & Freq./150 & Perc./100 & Freq./150 & Perc./100 \\
\hline $\begin{array}{l}\text { Cast in-situ concrete } \\
\text { paved walkway }\end{array}$ & 49 & 32.7 & 54 & 36.0 & 47 & 31.3 & 42 & 28.0 \\
\hline $\begin{array}{l}\text { Precast concrete paved } \\
\text { walkway }\end{array}$ & 11 & 7.3 & 8 & 5.3 & 10 & 6.7 & 11 & 7.3 \\
\hline $\begin{array}{l}\text { Cast in-situ concrete } \\
\text { paved driveways }\end{array}$ & 41 & 27.3 & 19 & 12.7 & 14 & 9.3 & 14 & 9.3 \\
\hline $\begin{array}{l}\text { Precast concrete } \\
\text { driveways }\end{array}$ & 7 & 4.7 & 3 & 2.0 & 1 & 0.7 & 5 & 3.3 \\
\hline Sand walkway & 65 & 43.3 & 65 & 43.3 & 66 & 44.0 & 69 & 46.0 \\
\hline Sand driveway & 4 & 2.7 & 0 & 0.0 & 0 & 0.0 & 1 & 0.7 \\
\hline $\begin{array}{l}\text { Cast in-situ concrete } \\
\text { parking }\end{array}$ & 18 & 12.0 & 4 & 2.7 & 3 & 2.0 & 2 & 1.3 \\
\hline Precast concrete parking & 4 & 2.7 & 4 & 2.7 & 4 & 2.7 & 4 & 2.7 \\
\hline $\begin{array}{l}\text { Undefined concrete } \\
\text { finished spaces }\end{array}$ & 12 & 8.0 & 2 & 1.3 & 2 & 1.3 & 2 & 1.3 \\
\hline
\end{tabular}

Table 7. Soft landscape treatment of the open spaces

\begin{tabular}{|c|c|c|c|c|c|c|c|c|}
\hline \multirow[t]{2}{*}{ Landscape treatment } & \multicolumn{2}{|c|}{ Front } & \multicolumn{2}{|c|}{ Left side } & \multicolumn{2}{|c|}{ Right side } & \multicolumn{2}{|c|}{ Rear side } \\
\hline & Freq./100 & Perc./100 & Freq./150 & Perc./100 & Freq./150 & Perc./100 & Freq./150 & Perc./100 \\
\hline Lawns & 25 & 16.7 & 26 & 17.3 & 28 & 18.7 & 22 & 14.7 \\
\hline Maintained plant hedges & 33 & 22.0 & 11 & 7.3 & 3 & 2.0 & 7 & 4.7 \\
\hline $\begin{array}{l}\text { Unmaintained plant } \\
\text { hedges }\end{array}$ & 2 & 1.3 & 0 & 0.0 & 0 & 0.0 & 0 & 0.0 \\
\hline Stone paving & 7 & 4.7 & 3 & 2.0 & 3 & 2.0 & 3 & 2.0 \\
\hline $\begin{array}{l}1 \text { to } 5 \text { in number of Non- } \\
\text { shady trees }\end{array}$ & 31 & 20.8 & 20 & 13.4 & 34 & 22.7 & 13 & 8.7 \\
\hline Foundation planting & 1 & 0.7 & 0 & 0.0 & 2 & 1.3 & 5 & 3.3 \\
\hline Shady trees & 26 & 17.3 & 10 & 6.7 & 8 & 5.3 & 1 & 0.7 \\
\hline Decorative palms & 1 & 0.7 & 0 & 0.0 & 0 & 0.0 & 0 & 0.0 \\
\hline Flowering plants & 32 & 15.4 & 17 & 11.3 & 7 & 4.6 & 17 & 11.4 \\
\hline $\begin{array}{l}\text { Assorted colours of } \\
\text { flowering plants }\end{array}$ & 13 & 8.7 & 1 & 0.7 & 0 & 0.0 & 0 & 0.0 \\
\hline Swimming pool & 0 & 0.0 & 1 & 0.7 & 0 & 0.0 & 0 & 0.0 \\
\hline Water fountain & 0 & 0.0 & 1 & 0.7 & 0 & 0.0 & 7 & 4.7 \\
\hline
\end{tabular}

back in particular implies that statutory planning guidelines are followed to ensure that minimum setback is allowed between the building line and the site boundaries at the side(s) of the building that abuts the access road(s).

From Table 8 , generally there is significant relationship between availability of open spaces as setback from property line in the front to building line and landscape qualities. This pattern of significant relationship also applies to open space at other sides of the buildings and their landscape quality.

\section{CONCLUSION AND RECOMMENDATION}

Urban aesthetics is hinged upon building massing in terms of available open spaces around buildings and the landscape quality of the spaces. This unmistakable relationship has been re-affirmed by this study. The major findings of the study can be summarized as follow:

1. Regard for statutory planning regulations on access to building plots, nature of perimeter fencing and allowable minimum set-backs has direct impact on the quality of building massing in terms of quantity of available open space in residential neighbourhoods.

2. There was a general non-conformity to minimum allowable width of access road (138 buildings, $92.0 \%)$ and less than $5.0 \mathrm{~m}$ set-back from property line in front (110 buildings, 73.3\%) possibly because of high cost of building land in the neighbourhoods.

3. There is a general dearth of landscape quality in the study area and where they are ever scantly present, they were never designed nor adequately maintained. 
4. Like any other quality variable in the urban fabric, landscaping is associated with economy because majority of the available open spaces around buildings in the study area were left bare and untreated or rather "treated" with ordinary sand as drives, parking, and walks which does not require serious installation nor maintenance cost. Similarly, soft landscape elements that has high initial and maintenance cost were sparingly used while hard elements like concrete paving that has low maintenance cost were more used without recourse to their thermal comfort implycations.

In view of these, the following recommenddations are necessary:

1. Adequate attention should be paid to the preplanning of the land use of institutional campus neighbourhoods to avoid the consequences of sprawling and uncontrolled land use. This is necessary because of the high possibility of campus influence on the physical growth of these neighbourhoods.

2. Minimum standards of statutory planning regulations on building plot accessibility, setbacks and fencing should be ensured in abutting neighbourhoods of institutional campuses.

3. There is need for awareness and education of developers around institutional campuses on the multiple importance and benefits of properly designed, installed and maintained landscaping of open spaces around buildings in these neighbourhoods.

4. Landscape design should be made an important aspect of building and planning permit processing of developments around institutional campuses and urban areas at large.

\section{REFERENCE}

Adedeji, J.A., Bello, Y. O. and Oyedemi, D.T.A. (2009). "University Off-campus Accommodation System, A Catalyst to Physical Development: The LAUTECH Experience" Journal of Environmental Studies and Policy Analysis, 1(1):101-110

Akingbohungbe, D.O. (2003a). "Adequate Housing and Sustainable Development in Nigeria" Journal of Urban and Environmental Research 3(1):15-18.

Azwar, D.H. and Ghani, I. (2009). "The Importance of Green Space: Towards a Quality Living Environment in Urban Areas" Archnet-IJAR,
International Journal of Architectural Research, Volume 3- Issue 1-March: 245-262.

Braines, C. (2000). "A Forest of Other Issues" Landscape Design, no. 294, pp. 46-47.

Campbell, K. (2001). Rethinking Open Space, Open Space Provision and Management: A way Forward, Report Presented by Scottish Executive Central Research Unit, Edinburgh, Scotland, UK.

Carmona, M., Heath, T., Oc, T., and Tiesdell, S. (2003). Public Places Urban Spaces-The Dimensions of Urban Design, Oxford: Architectural Press p.159.

Fadamiro, J.A. (2000). "Outdoor Spaces and their Landscape Qualities: A Comparative Analysis of Three Neighbourhoods in Lagos, Nigeria." Journal of Urban and Environmental Research, 2(1): 55-67.

Fadamiro, J.A. and Atolagbe, A.M.O. (2006). "Urban Environmental Sustainability: A Challenge to Effective Landscaping in Nigeria" Dimensi Teknik Arsitektur Vol. 34, No. 1, July 2006:4451. Available at http://www.petra.as.id/-pusht/ ournals/dir.php?departmentID=ARS.

Jagboro, G.O. (2000). Sustainable Development and Cost Behaviour of Landscape Elements in Urban Residential Buildings in Lagos Metropolis in Effective Housing in the $21^{\text {st }}$ Century Nigeria, O.B. Akinbamijo et al (eds.) pp. 96-100 Akure: The Environment Forum, Federal University of Technology.

Jones, N. (2001). “Green Leaves", Landscape Design, no. 299 pp. 30.

Jones, N. (2003). "Function of Trees: Breathing Space", Landscape Design, No 321, pp. 20-22.

Lasisi, A.L. and Arowosegbe, O.S. (2005) "Perception of Urban Landscaping Problems: Case Study of Residential Building Environments in Ilaro". Journal of Land Use and Development Studies Vol. 1, No. 1.

Oyelami, O.A. (2005). The Myth, The Mould and The Microbe, Inaugural Lectures Series 182 Obafemi Awolowo University, Ile-Ife O.A.U. Press Limited.

Tipple, G. (2001). "The Impact of Regulations on the Livelihoods of People Living in Poverty" available at http://practicalaction.org/docs/shelter/ G\%/20Tipple\%20Case\%20Studydoc, Accessed on $11 / 02 / 2010$. 